\title{
SCORCHERS AND SHOPPERS: WOMEN, EARLY AUTOMOBILISTS' CLOTHING AND FASHIONS FOR “MILADY OF THE ELECTRIC"
}

Pam McKinlay

Fashions for Milady of the Electric

New Fall Garments to Be Seen in Electrics on the Boulevards and Roads
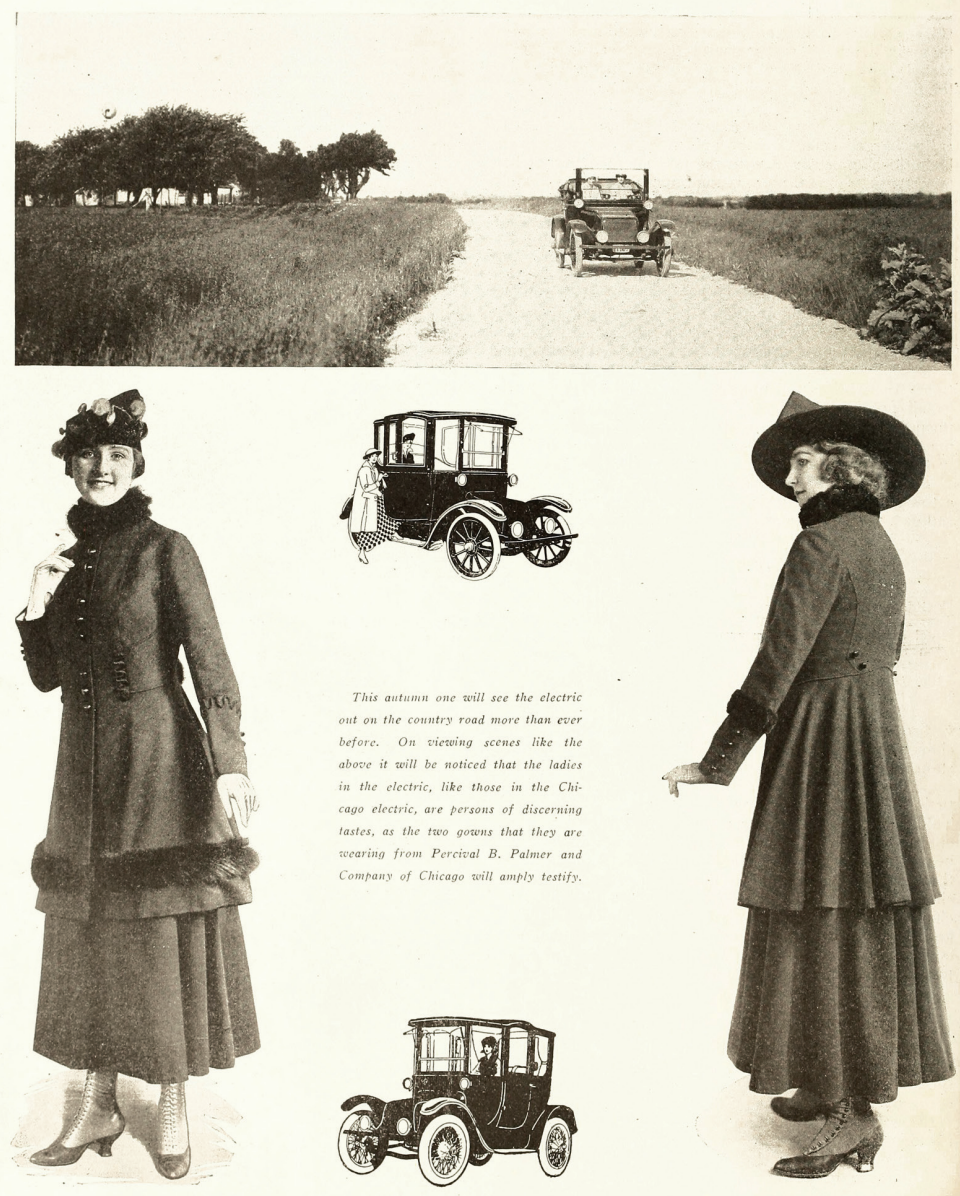

Figure I. Fashion plate for "Milady of the Electric," c. 1916. Creative Commons License.' 
The popularity of automobiles exploded shortly after the turn of the twentieth century, creating a lucrative new market for lines of specially designed recreational clothing. A pastime of the affluent and adventurous, early motoring had its own special couture; the centrepiece was the motoring or automobile coat, a shapeless yet functional piece of attire for both men and women. As more women got behind the wheel, tensions between female independence and perceptions of women's proper place in the world became more apparent. Electric vehicles were touted as the lesser of two evils for forward-thinking women with a bent for driving. The fashion market flourished, with designs appealing to "Milady of the Electric" marketed as a way of maintaining both femininity and independence (but not too much).

\section{HAY, STEAM, ELECTRONS AND GAS}

We think of electric vehicles as a futuristic, twenty-first-century technology. However, in the early 1900s, there were 300 companies making electric vehicles. At the turn of the twentieth century, 40 percent of automobiles in America were powered by steam, 38 percent by electricity, and 22 percent by gasoline. ${ }^{2}$ Gas and steam cars required strength and time to start, with steam vehicles requiring up to 45 minutes' start-up time. Steam-powered cars died out with hay (horses), leaving the other two contenders for domination of the roads. There were more than 30,000 electric vehicles on the roads in the United States in 1900 and they looked like they were here to stay. The hiatus between then and now, when electrics are once more on the ascendant, was filled by a story of energy and the politics of big oil - a story which has been told elsewhere. ${ }^{3}$

Early gasoline- (petrol-) powered cars required manual strength and technical know-how to drive. Physical effort was required to start the car by cranking and, when driving, with changing gears. Kickbacks from cranking caused bruising and broken thumbs, and roadside injuries abounded as a result of the need to restart stalled engines in congested traffic. Early automobiles were open, cold and dusty. Petrol cars were also noisy (unmuffled), smelly, were subject to excessive vibration and occasionally blew up - Clara Ford (wife of automobile magnate Henry Ford) referred to them as "explosion cars."

At the turn of the twentieth century, the lack of infrastructure was a barrier to longer journeys for both gas and electric motorised transport, both in terms of roading and refuelling. Roading was poor - marginal at best outside of urban centres. The earliest filling stations were pharmacies selling ligroin (petroleum ether). ${ }^{5}$ The increase in the popularity of electric cars was linked to the advent of domestic lighting, with light bulbs driving demand for infrastructure that could reach every home and be available to the general public. ${ }^{6}$

\section{DRESSING FOR ADVENTURE - AUTOMOBILE COATS}

Most early automobiles required wardrobe preparations for travel. Early gasoline combustion-powered cars were open, draughty, noisy, shaky, unreliable and smelly contraptions. Early cars had no roofs or doors and were driven mostly on dirt roads. New lines of sporting or leisure clothing were created alongside the new automobile technologies. The "car coat" (first called automobile or motoring coats), ${ }^{7}$ hats, specialty driving gloves and goggles (offering protection from dust and the occasional pebble) were necessities for men, matched by car coat, gloves, hats and veils and/or goggles for women (Figures 2, 3 and 5). In the early days of motoring, cars were the province of the very rich. Motoring clothes became a statement of status, class and luxury, with people arriving at functions in motoring attire to appear as if they had arrived by automobile.

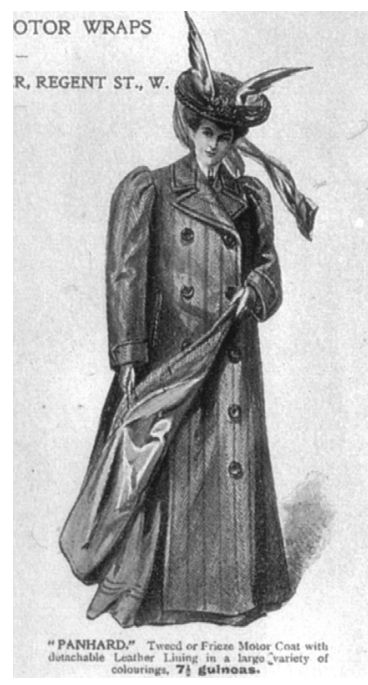

Figure 2. Automobilists' motoring coat for women.

Image: Wikimedia commons: Public Domain. 
The car coat was first designed as a functional, fulllength over-garment to provide maximum warmth and coverage in order to protect the driver and passengers from the elements: wind, wet, cold and dust and, in the case of petrol cars, from oil and exhaust fumes - as well as staying warm during frequent roadside repairs and breakdowns (Figure 2). Car coats came in fur, leather and heavy wool, ${ }^{8}$ with a move to lighter fabrics ('duster coats') in linen or alpaca wool ${ }^{9}$ for the warmer seasons when the enemy was dust rather than mud. Car coats have survived in the clothing realm as a shorter variant of the early garment and - in a design closer to the original car coat lineage - in the greatcoat.

Virginia Scharff described the new sportswear as dressing for duress, not style:

Girded in corsets and petticoats and forty pounds of underskirts and overskirts, cloak and formidable hat, she is clad for immobility... First, the duster, or motoring coat. It might be made of leather or rubber or fur; in all cases it was hot and heavy, adding yet more poundage to her already heavily freighted body. Then there were a host of devices to protect face, eyes, hair and hat. These ranged from simple, if cumbersome, goggles and heavy veils to more

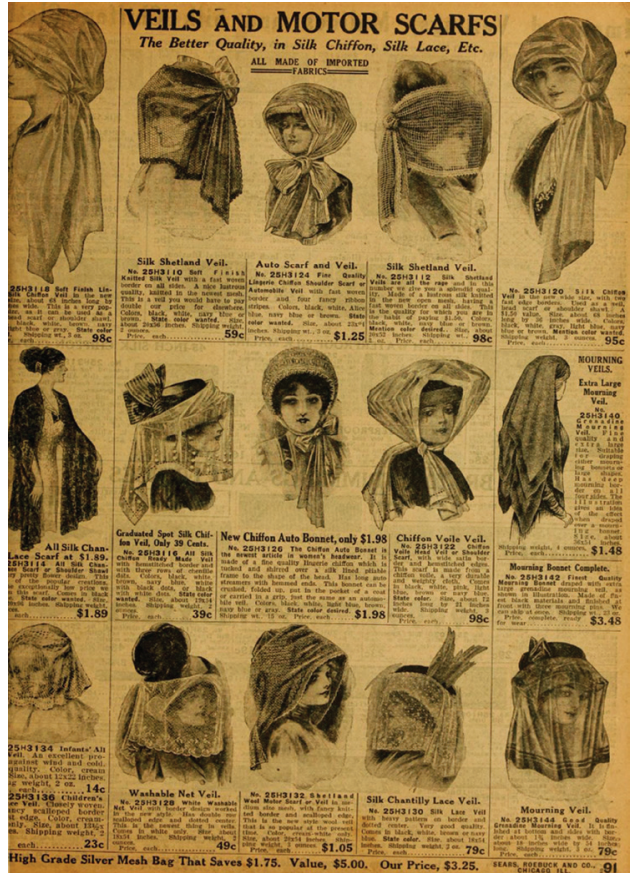

Figure 3.Women's hats also included removable veils as dust shields to protect the wearer's face as in this catalogue from Sears.' elaborate contraptions. On rainy days, the motoring woman might choose a waterproof rubber hood and shoulder cape, looking rather like someone who planned to take a shower with all her clothes on. An all-weather motoring mask for women approximated a large bucket inverted over her head. Made of mica with a translucent linen veil, it closely resembled the protective head covering worn by modern workers who handle plutonium. ${ }^{10}$

\section{ENTER THE ELECTRIC CAR}

Electric vehicles were different. They were free from the noise and smell of gasoline-powered cars and offered a gentle, smooth ride compared with the vibration of the latter vehicles. ${ }^{12}$ They were more reliable than their gas cousins and were equipped with an electric starter, ${ }^{13}$ later widely adopted in all motor vehicles as a concession to female frailty. ${ }^{14}$ They required no cranking and were easy to operate $-a$ child could drive them (even a woman):

A car charged with electricity can be driven by a child. There is practically nothing to go out of order or to go wrong. A hard-working goblin has been imprisoned in the accumulators, and for the number of miles which he is condemned to serve the car is bound to run. Nothing is easier than to drive a properly-made electric motor car. (Otago Daily Times, 25 June 1900) ${ }^{15}$

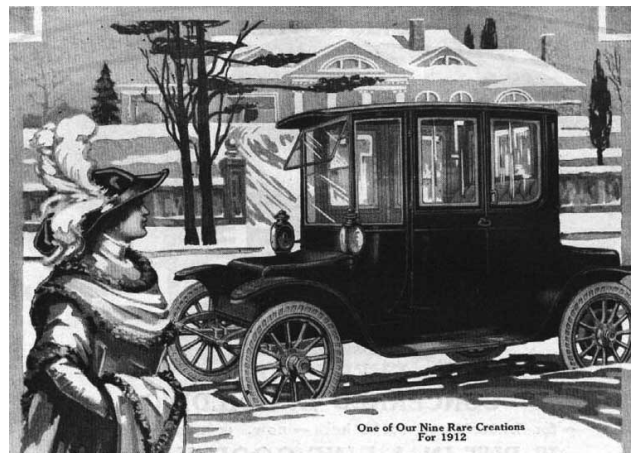

Figure 4. Detroit Electric Vehicle Advertisement. Image credit: Wikimedia Commons, Public Domain 


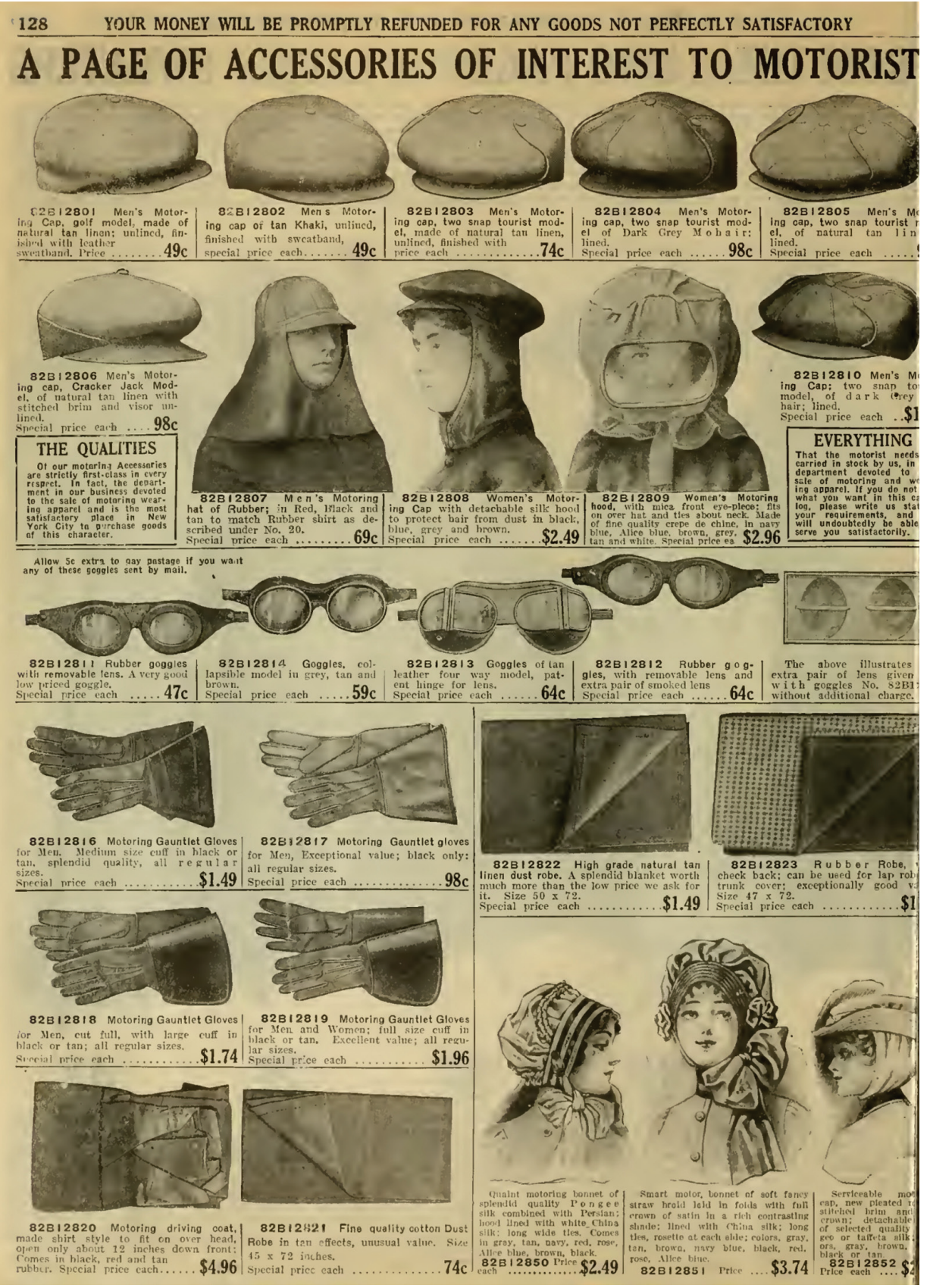

Figure 5. Women's hats also included removable veils as dust shields to protect the wearer's face as in these catalogues from Macy's."

Image Credits - Sears Catalogue - Veils and Motor scarves, http://www.archive.org/stream/catalogno I2400sear\#page/9I/ mode/ I up and Macey's Catalogue, A Page of Accessories of Interest to Motorists https://archive.org/stream catalogueno I 6spro0macy\#page//30/mode/2up. 
Many early models were custom-built, their design based on enclosed carriages (aka horseless carriages) to insulate the occupants from the noise and smell of other traffic. In addition, an enclosed vehicle freed a woman from the necessity of a male companion as she made her way about public spaces in the city, and freed her from the privations of public transport. In 1907, the Society for the Protection of Passenger Rights in New York City noted that crowding had reached "the point of indecency" in public transport. At the end of the nineteenth century, a fleet of electric cabs was introduced to the streets of London. They were nicknamed Hummingbirds, due to the humming noise they made. Women without their own wheels would happily wait for an electric taxi to enjoy the perceived benefits of a clean, smooth ride - Hummingbirds were preferred over "explosion cars" any day. By I899, 90 percent of New York City's taxi cabs were electric vehicles. The Electric Vehicle Company operated 2000 electric vehicles, along with the attendant charging infrastructure needed to support this new enterprise. ${ }^{16}$

\section{GAS IS FROM MARS, ELECTRICITY IS FROMVENUS ${ }^{17}$}

As we have seen, only the affluent could afford to drive in the early days of automobiles. The Electric Vehicle Assocation's (EVA) marketing messages appealed to luxury, convenience and those aspiring to both. ${ }^{18}$ Luxury firm, the Baker Motor Vehicle Company, marketed themselves as the "aristocrats of motordom," providing reliable vehicles for businessmen for whom time was money. Although primarily targeted at women, electrics were seen as having sartorial benefits for doctors, bankers and other professionals who required similar protection for their clothing when out and about in town. Driving an electric had many practical bonuses. Time and energy were saved, with no tiresome (sweat-inducing) cranking and stalling; drivers' suits would not get crumpled, rumpled, windblown and spattered, and one could arrive in style sans shapeless carcoat.

These vehicles were first advertised as "Electric Sensations for Men." However, as the electric car became increasingly associated with women they were eschewed by men, despite their reliability and cleanliness. They were classy, but not masculine enough. To counter this perception, fake parts such as false radiators were put on 'men's electrics' and men's vehicles were designed as 'sporty, more macho options, with features such as lowered suspension.

\section{OUT OF BOUNDS:THE LADIES' AUTOMOBILE CLUB, SCORCHERS AND SPEED QUEENS}

Driving gave women freedom and independence as early as 1898. Cars provided mobility and independence without the ridicule attracted by other forms of personal transport such as the bicycle and the "reform dress" and bifurcated dresses associated with it. ${ }^{19}$ As more forward-thinking women got behind the wheel, tensions arose between conventional perceptions of a woman's place and their desire for independence and personal mobility. As Matthew Lasar says, "Clearly a society that had yet to decide whether women could vote, enter professions, or even use the phone to invite friends to dinner parties was experiencing just a little bit of anxiety about females driving cars." 20

Nowhere was this tension more evident than in the early days of motor sport. The Ladies' Automobile Club was Great Britain's first dedicated motor club for women. The club was mostly social, although some women were involved in early racing driving. ${ }^{21}$ Pioneering racing driver Dorothy Levitt was a "scorcher." Dubbed the fastest woman in the world, she wore an extravagant green dress (often dressing to match the colour of her car) to the track at Herkomer in 1907, but was barred from racing at the newly opened Brooklands, the first purpose-built racetrack in the world, in 1908.22 The rules were relaxed for a ladies' handicap in 1908, at which the ladies wore colour-coordinated outfits and gloves with their skirts tied securely with pieces of cord to stop them riding up over their knees. Women were banned again following this race until ladies-only handicaps were once more allowed in 1928.

As well as a racing driver, Dorothy Levitt was a motoring journalist and wrote a book for women drivers. In The Woman and the Car (1909), ${ }^{23}$ her aim was to dispel the myth that women were not strong enough to get behind 
the wheel and to show that they were technologically competent, as a counter to prevailing sentiment as illustrated by the following quotation: "A woman's brain evolves emotion rather than intellect; and whilst this feature fits her admirably as a creature burdened with the preservation and happiness of the human species, it painfully disqualifies her for the sterner duties to be performed by the intellectual faculties." ${ }^{24}$ She provided advice on what to wear behind the wheel, with practicality as well as femininity in mind. "Under no circumstance wear lace or fluffy adjuncts to your toilet. There is nothing like a thick frieze, homespun or tweed coat lined with fur. Do not heed the cry,'nothing like leather.' Leather coats do not wear gracefully."

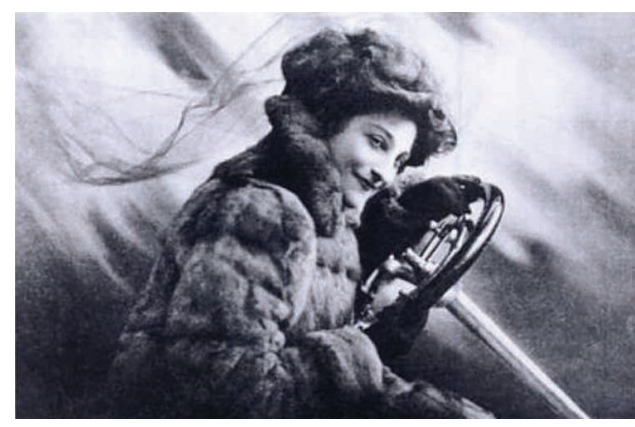

Figure 6. Pioneering racing driver Dorothy Levitt wearing a fur car coat and veil; from the frontispiece of her book The Woman and the Car, 1909.

Image credit: Wikimedia Commons, Public Domain.

In her book, Levitt shares advice on servicing one's car, with handy tips on how to clean a carburettor with a hat pin (as illustrated in hands-on photographs) and recommends keeping a hand mirror in the tool drawer under the driving seat to enable the motorist to see behind her when necessary. The idea caught on and it is to Levitt that we owe the invention of the rear-view mirror. ${ }^{25}$ Other innovative early women drivers were Mary Anderson, who invented the first windshield wiper, ${ }^{26}$ and Bertha Benz, who pioneered brake linings and the second gear. ${ }^{27}$

\section{SHOPPERS AND SOCIALITES - STAYING IN BOUNDS AND KEEPING UPWITHTHE ROCKEFELLERS}

In 1910, under the headline "MORE COMFORTS FOR WOMEN IN AUTOS: Manufacturers Have Studied the Many Details for Women's Demands in the 191 I Models," New York Times technical correspondent Charles Duryea stated that "it has simply been assumed that women would not drive, and so long as the tonneau was roomy, comfortable, and well inclosed her needs were supposed to be well met." 28

One of the more interesting arguments for women driving was the reconciliation of driving with modern motherhood and the fashionable belief that healthy young children needed fresh air: "in no way can a child get so much air in so little time as by the use of the automobile ... It is the light electric runabout which deserves the title of scientific perambulator."29

Eventually, the restrictive features of luxury urban electric cars (less power than gasoline-powered cars and limited range) were seen as being wholly advantageous for females and a practical compromise for women who would insist on driving. Electrics were seen as being best suited for running errands around town and thus a way of keeping women within the domestic sphere. An electric was a very suitable vehicle for driving to town, but not beyond! ${ }^{30}$

In America, many of the wives of nineteenth-century American innovators and movers and shakers drove electric vehicles, including the Rockefellers (founders of the Standard Oil Company). The Edison, Ford and Packard women all drove electric, and the first five presidents' wives followed the same path. ${ }^{31}$ Such was the demand that the superintendent of the Detroit Electric Car Co. employed his daughter, Lillian Reynolds, to sell to these upper-class women. ${ }^{32}$ In Europe, the trend-setters were the aristocracy including several kings and queens. At this stage, many electrics were more like mobile parlours on wheels, complete with monogramed interiors. "One does not so much enter the Baker as climb it. Once inside, it's apparent that the designers were less intent on building a vehicle than they were in creating an ornate mobile parlor ... much like the booth of a Victorian tea room." ${ }^{33}$ 


\section{PARLOUR AWAY FROM HOME}

Growing competition between auto manufacturers saw the increasing 'domestication' of the automobile to suit the market needs of upper-class women. Manufacturers sought to cater to female 'needs' by designing enclosed carriages with high ceilings intended to keep ladies' tall hats from being crushed and their hair from being mussed. ${ }^{34}$

These vehicles were designed from the inside out with extravagant interior styling, with a focus on upholstery and paintwork. Features included custommonogramed interiors, velvet upholstery, sophisticated

lighting and heating, built-in vanity cases and vases for flowers. A rudder-like arrangement in place of a steering wheel meant that the car could be driven from the front or back seat, whichever was more convenient. ${ }^{35} \mathrm{~A}$ further nod to the increasing refinement of electric vehicle design was the first use of curved window glass in a production automobile, an expensive and complex feature to produce.

"These were women's shopping cars," says classic car collector Jay Leno. "There were thousands of these in New York, from about 1905 to 1915. There were charging stations all over town, so ladies could recharge their cars while they were in the stores." 36

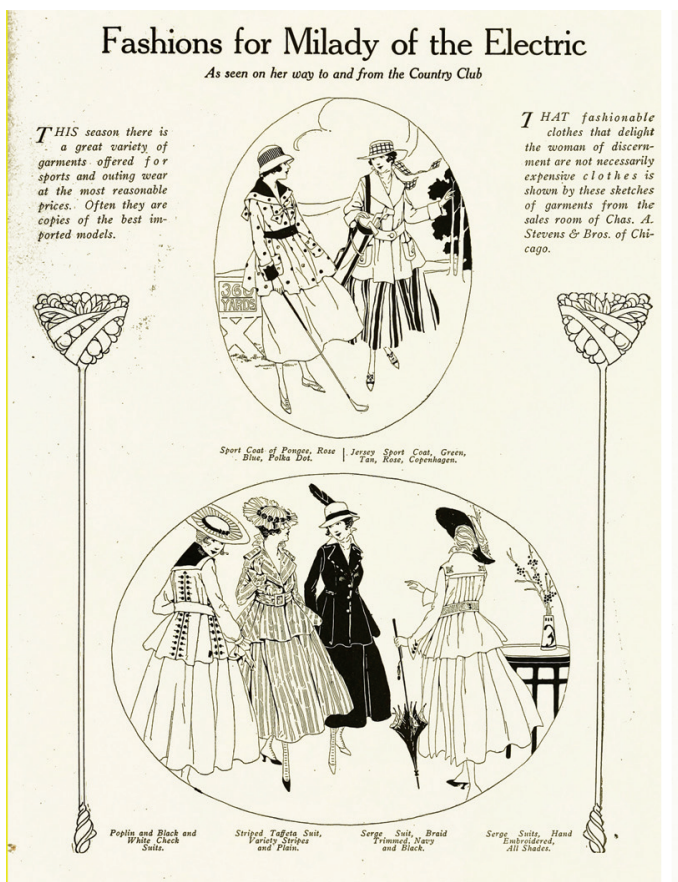

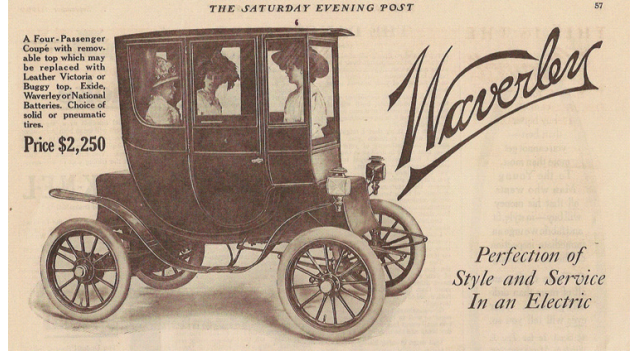

Figure 7.Waverley Electric Vehicle Advertisement. Image credit: $v$ Wikimedia Commons, Public Domain.

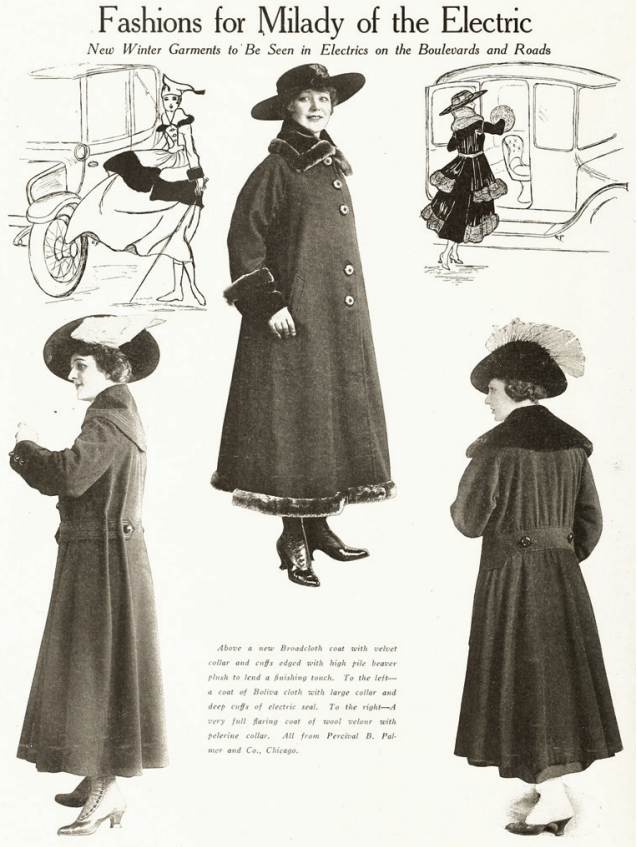

Figures 8 and 9. Fashion plates for "Milady of the Electric," c.1916.

Creative Commons License. ${ }^{37}$ 
There was no longer any need for the cumbersome car coat in such an elevated mode of transport, driven by the cream of female society. Marketers quickly changed tack to tout the virtues of electric vehicles and their fashion benefits for women. One could throw away shapeless and style-less autoist's slip-ons, coveralls and dust coats if one simply drove an electric. As more women got behind the wheel, new fashion lines appeared each season in women's journals and leading newspapers directed to fashionable female drivers, or "Milady of the Electric."

\section{CONCLUSION}

Only the affluent could afford the new automobile machines that appeared at the end of the 1890s. The early days of motoring were a time of outdoor adventure which was accompanied by new lines of sportswear, functional attire to wear over street or evening clothing. Early women drivers were forward-thinking and challenged notions of impropriety on the road and, more shockingly, on the race track. Of the two main forms of motorised vehicles (gas and electric), electrics were seen as the lesser of two evils and far more suitable for women to drive. Clothing design kept step with each stage of motoring evolution. At each stage, women who took the wheel were appropriately attired in the style attuned to the vehicle they were driving, whether they were scorchers or shoppers. The fashion advantages of driving electric were one of the marketing strategies targeting women, encouraging them to remain in the appropriate realm for femininity and domestic life.

Pam McKinlay (미 0000-0002-1731-6437) has a DipHSc in clothing/design and a BA in art history from the University of Otago. She works part-time at the Dunedin School of Art and the Research Office, Otago Polytechnic, and is a modern EV-eryday woman. 
I "Fashions for Electric Car Women - Ad circa 1916," 22 October 2013, http://ctgpublishing.com/fashions-for-electric-carwomen-ad-circa-1916/ (accessed 21 July 2019).

2 https://www.britannica.com/technology/automobile/History-of-the-automobile.

3 Peter B Doran, Breaking Rockefeller:The Incredible Story of the Ambitious Rivals who Toppled an Oil Empire, audiobook (London: Penguin Audio, 2006); Chris Paine, dir., Who Killed the Electric Car? (New York: Sony Pictures Classics, 2006).

4 Safety was a frequent theme in electric automobile advertising. Certainly, electric cars were safer to start than hand-cranked gasoline cars, but manufacturers also stressed that electrics were safe to charge. An illustration, from a 1917 Rauch and Lang Carriage Company catalogue, makes the point vividly with a child holding the plug while mother turns on the power. See www.thehenryford.org/collections-and-research/digital-collections/artifact/95366\#slide=gs-333917 2 (accessed 21 July 2019).

5 Sarah Crofts, "Women in Motorsport \& Social History: Berta Benz," Beaulieu, I February 20 I 6, https://www.beaulieu.co.uk/ news/women-in-motorsport-social-history-berta-benzl (accessed 21 July 2019).

6 '“'Do it electrically.'... Already that wonderful force, generated in the grey power-house on the banks of the Rakaia River is lighting our homes and city streets, turning the giant wheels of industry, cooking our food, and driving our vehicles... You know, too, that our city is fast becoming a clean, 'smokeless' city land and that we are saving from 60,000 to 70,000 tons of coal annually ... ." "Electric Power. In Home and Street," The Sun, 6 November 19 | 8, https://paperspast.natlib.govt.nz/newspapers/ SUNCHI9I8I 106.2.40 (accessed 21 July 2019)

7 Curt McConnell, "A Reliable Car and a Woman Who Knows It": The First Coast-to-Coast Auto Trips by Women, $1899-1916$ (Jefferson, NC: McFarland, 2000).

8 Valerie Cumming, CW Cunnington and P Cunnington, The Dictionary of Fashion History (Oxford: Berg, 2010 ), 135.

9 Ibid.

10 Virginia Scharff, Taking the Wheel: Women and the Coming of the Motor Age (Albuquerque, NM: UNM Press, 1992), I5- 16.

II Catalogues - Sears, Roebuck and Co., Catalog No. 124 (1912), "Veils and Motor Scarfs," https://mww.archive.org/stream/ catalognol2400sear\#page/91/mode/lup and and Macey's Catalogue, A Page of Accessories of Interest to Motorists, Catalogue no. 16, spring/summer / R. H. Macy \& Co., 128 https://archive.org/stream/cataloguenol 6spr00macy\#page/I30/ mode/2up (Retrieved 21 July 2019)

12 The Sun, 6 November 1918,https://paperspast.natlib.govt.nz/newspapers/SUNCHI9181 106.2.40 (accessed 21 July 2019).

13 EE Schwartzkopf, Automobile Topics, 22 (1911), 1204.

I4 Etta Place, "Crazy Woman Driver! Gender Divisions in the Early Days of the Automobile," The History Bandits, I June 20 I5, https://thehistorybandits.com/20 I 5/06/0 I/crazy-woman-drivers-gender-divisions-in-the-early-days-of-the-automobile/. Kettering himself was not intending to make a "gallant bow" to female drivers with his invention. He thought the self-starter, a so-called "feminine frill," would eventually become a standard feature of every automobile because of its universal utility (accessed 21 July 2019).

15 Otago Daily Times, 25 June 1900.

16 Scharff, Taking the Wheel, 49.

17 Lynne Mason, "Electric Car History," Electric Cars are for Girls, https://www.electric-cars-are-for-girls.com/history.html (accessed 21 July 2019).

I8 "Early Electric Cars," Chuck's Toyland:A Historical Preservation from Charles D. Test, 1912 Electric Vehicle Association Of America "We'll go right over to the Bank- my Electric is at the door" Electric Vehicle Association Of America Boston New York Chicago, Motor Age, July I I, 1912, 106 https://www.chuckstoyland.com/category/automotive/early-electric-cars/ (accessed 21 July 2019).

19 Julie Wosk, Women and the Machine: Representations from the Spinning Wheel to the Electronic Age (Baltimore, MD: John Hopkins University Press, 2003), I 16.

20 Matthew Lasar, "Electric Ladyland: When Battery-powered Cars were Built for Women," arstechnica, I8 April 20।2, https:// arstechnica.com/gadgets/2012/04/electric-ladyland-when-battery-powered-cars-were-built-for-women/ (accessed 21 July 2019).

21 Rachel H-G, "The Ladies' Automobile Club," Speedqueens: Women in Motorsport from 1897 to the Present Day, I4 October 2017, http://speedqueens.blogspot.com/search/label/Edwardian\%20and\%20Victorian\%20racers (accessed 21 July 2019).

22 Sarah Crofts, "Women in Motorsport \& Social History: Belles of Brooklands," Beaulieu, 3 August 20 I 6, https://www.beaulieu. co.uk/news/women-in-motorsport-social-history-the-belles-of-brooklands/ (accessed 21 July 2019).

23 Dorothy Levitt, The Woman and the Car: A Chatty Little Handbook for all Women who Motor or who Want to Motor (London: John Lane, 1909). 
24 E Frost-Knappman and K Cullen-DuPont, Women's Suffrage in America: An Eyewitness History (New York: Facts on File, 1992), 279.

25 Sarah Crofts, "Women In Motorsport \& Social History: Dorothy Levitt," Beaulieu, https://www.beaulieu.co.uk/news/womenin-motorsport-social-history-dorothy-levitt/ (accessed 21 July 2019).

26 HVA, "Women at the Wheel," Hagerty, 24 October 2012, https://www.hagerty.com/articles-videos/Articles/2012/I0/24/ Women-at-the-Wheel/ (accessed 21 July 2019).

27 Crofts, "Women in Motorsport \& Social History: Berta Benz."

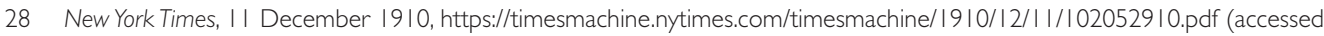
21 July 2019).

$29 \mathrm{CH}$ Claudy, Woman's Home Companion, 1907, cited in in Virginia Scharff, "Femininity and the Electric Car," Automobile in American Life and Society, http://www.autolife.umd.umich.edu/Gender/Scharff/G_casestudy.htm (accessed 2I July 20I9).

30 Lasar, "Electric Ladyland."

31 " "1912 Baker Electric Victoria, Used by Five First Ladies of the United States," The Henry Ford, https://wmw.thehenryford.org/ collections-and-research/digital-collections/artifact/195103 (accessed 21 July 2019).

32 The "first woman ever to sell a horseless carriage," Lillian learned to drive when she was I 5 and started in sales when she was 19."'Electric cars were for ladies,' she said ... 'It wasn't ladylike to drive a gasoline auto. With electric cars there was no oil or dirt to shoot up through floor boards, there was no dust, and they were almost automatic - you didn't have to know a thing about mechanics."' The Michigan Daily, I4 April 1946, https://digital.bentley.umich.edu/midaily/mdp.3901507|756/96/204/ (accessed 21 July 2019).

33 Dexter Ford, "Back to the Future in a 98-year-old Electric Car," New York Times, 5 August 2007, https://www.nytimes. com/2007/08/05/automobiles/05BAKER.html. (Interview with Jay Leno.)

34 Brendan McAleer, "Clean and Quiet:The I00-year-old Advantages of an Electric Vehicle," Hagerty, 22 September 20 I 7, https:// www.hagerty.com/articles-videos/articles/2017/09/22/detroit-electric.

35 The Michigan Daily, 14 April 1946.

36 Ford, "Back to the Future;"'The New York Edison Company's Automobile Bureau published a booklet for electric car owners. It included a map and address listings of charging stations in New York City. Stations outside the immediate area, as far as Boston and Philadelphia, were also listed. "'Electric Automobile Charging Stations in New York City and Vicinity', with Maps, Second Edition, August 1923," https://www.thehenryford.org/collections-and-research/digital-collections/artifact/17/903 (accessed 21 July 2019).

37 "Fashions for Electric Car Women - Ad circa 1916," 22 October 2013, http://ctgpublishing.com/fashions-for-electric-carwomen-ad-circa-1916/ (accessed 21 July 2019). 